\title{
Reacții adverse la tratamentul antiretroviral sau altă boală?
}

\author{
Mariana Stănescu ${ }^{1}$, Augustin Cupșa ${ }^{2}$, Cristiana Eugenia Simionescu ${ }^{3}$, \\ Adina Andreea Turcu ${ }^{1,4}$, Eugenia-Andreea Marcu', Florentina Dumitrescu ${ }^{1,2}$ \\ ${ }^{1}$ Spitalul Clinic de Boli Infecțioase și Pneumoftiziologie „Victor Babeș“, Craiova, România \\ 2Departamentul de Boli Infecțioase, Universitatea de Medicină și Farmacie, Craiova, România \\ ${ }^{3}$ Departamentul de Anatomie patologică, Universitatea de Medicină și Farmacie, Craiova, România \\ ${ }^{4}$ Departamentul de Sănătate orală, Facultatea de Medicină Dentară, \\ Universitatea de Medicină și Farmacie, Craiova, România
}

\begin{abstract}
REZUMAT
Sindromul inflamator de reconstructie imună (IRIS) este un răspuns inflamator paradoxal, care poate să apară la pacienţii infectaţi cu virusul imunodeficienței umane (HIV), în primele săptămâni după inițierea terapiei antiretrovirale (ART). Se poate manifesta fie prin demascarea unei infecții subiacente, fie prin agravarea simptomatologiei unei infecții oportuniste, diagnosticată deja și aflată în tratament. Prezentăm cazul unei paciente în vârstă de 24 de ani, diagnosticată în septembrie 2019 cu infecție HIV categoria C3, tuberculoză extrapulmonară cu determinări ganglionare și, probabil, splenice, bacteriemie cu Staphylococcus aureus, anemie hipocromă normocitară formă medie. S-au inițiat tratament antibacilar și ART (după 10 zile de la tratamentul pentru tuberculoză). După circa 2 săptămâni de la inițierea ART, pacienta a prezentat dureri lombare intense, cu iradiere la nivelul membrelor inferioare. A fost suspicionat IRIS (tuberculoză osoasă) sau o reacție adversă osoasă la ART, dar examenul imagistic (IRM-coloană lombară) evidențiază o hernie de disc lombo-sacrată, pacienta continuând ART, tratamentul antibacilar, adaugându-se tratamentul neurologic. Concluzii. IRIS trebuie avut în vedere la pacienții diagnosticați cu HIV în stadii tardive, la care introducerea ART poate fi urmată de agravarea sau apariția unei infecții oportuniste, punând probleme de tratament și diagnostic diferențial.
\end{abstract}

Cuvinte cheie: sindrom inflamator de reconstrucție imună, HIV, tuberculoză, terapie antiretrovirală

\section{INTRODUCERE}

Sindromul inflamator de reconstrucție imună (IRIS) este răspuns inflamator paradoxal, care poate să apară la pacienţii infectaţi cu virusul imunodeficienței umane (HIV) cărora li se iniţiază terapie antiretrovirală (ART), în primele săptămâni după începerea terapiei, ca urmare a restabilirii imunităţii pentru antigeni specifici infecțioși sau noninfecțioși [1].

IRIS apare sub două forme: IRIS „,demascare“ se referă la apariția unei infecții subiacente, anterior nediagnosticată, la scurt timp după începerea terapiei antiretrovirale (ART); IRIS ,paradoxal“ se referă la agravarea unei infecții tratate anterior după începerea ART. Acest sindrom are trei reguli: orice este posibil, nimic nu este așa cum era în epoca anterioară ART, IRIS nu înseamnă că ART a eșuat. Adesea, este dificil să se distingă între simptomele legate de infecția cu HIV și cele cauzate de ART [1]. Incidența globală IRIS rămâne necunoscută, fiind variabilă în raport cu populația studiată și incidența infecțiilor oportuniste. Factorii comuni favorizanţi identificaţi în declanşarea 
IRIS includ: sexul masculin, vârsta tânără, valori scăzute ale limfocitelor (Lf) CD4 la iniţierea terapiei $\mathrm{ARV}$, precum şi un raport scăzut CD4/CD8, scăderea rapidă a ARN HIV-1 după ART şi statusul de naiv la momentul diagnosticului infecţiei oportuniste, intervalul scurt între iniţierea tratamentului pentru infecţii oportuniste şi începerea ART. În general, IRIS apare la pacienţii cărora li s-a iniţiat ART în primele 2-3 luni de la iniţierea terapiei TBC, cu un vârf între 12 şi 15 zile, demonstrând că reacţia este relativ rapidă, ceea ce necesită măsuri de precauţie pe parcursul acestei perioade [2]. Supresia numărului de limfocite CD4 cauzată de HIV sau de medicație imunosupresivă se asociază unui răspuns imun ineficient față de anumite infecții. Beneficiile terapiei ART sunt demonstrate de monitorizarea imunologică (prin creșterea rapidă a CD4) și prin reacții virusologice (scăderea încărcăturii plasmatice virale HIV-1). În ciuda acestor beneficii, iniţierea terapiei este urmată de raspuns inflamator secundar cu deteriorare clinică (simptome generale nespecifice precum febra) și deteriorare a funcției anumitor organe [3]. Deoarece estimări exacte ale incidenței nu sunt încă disponibile, iar spectrul simptomelor și etiologiei este variabil, dar în creștere la pacienții cărora li se inițiază ART, IRIS rămâne încă o problemă de diagnostic și tratament [4].

\section{MATERIAL ȘI METODĂ}

Prezentăm cazul unei paciente în vârstă de 24 de ani, din mediul rural, fără antecedente personale patologice semnificative, care se internează în regim de urgență în Clinica de Hematologie din Spitalul Județean Drobeta-Turnu Severin pentru rectoragii, |astenie fizică marcată, scădere ponderală $(10 \mathrm{~kg}$ în 6 luni) și amețeală.

\section{REZULTATE}

Printre investigațiile biologice, se efectuează test Elisa-HIV1,2, cu rezultat pozitiv, și pacienta este transferată la Compartimentul HIV/SIDA - Spitalul Boli Infecțioase și Pneumoftiziologie „Victor Babeș“ din Craiova.

Examenul obiectiv la internare (septembrie 2019) evidențiază: stare generală influențată, afebrilă, deficit ponderal $\left(\mathrm{BMI}=17,91 \mathrm{~kg} / \mathrm{m}^{2}\right.$ indice de masă corporală), tegumente și mucoase palide, depozite micotice lingual, micropoliadenopatie generalizată, formațiune tumorală de aproximativ $1,5 \mathrm{~cm}$, bine delimitată, contur net, dură, mobilă pe planurile subiacente, sensibilă la palpare, cu localizare la nivel latero-cervical drept, sistem muscular hipotrof, țesut conjunctiv-adipos slab reprezentat, stetacustic pulmonar: murmur vezicular înăsprit bilateral, $\mathrm{SaO}_{2}=93 \%$, alură ventriculară $=83$ bătăi pe minut, tensiunea arterială $=110 / 74 \mathrm{mmHg}$, abdomen mobil cu mișcările respiratorii, dureros spontan și la palpare în hipocondrul drept și hipocondrul stâng, ficat cu marginea inferioară la $4 \mathrm{~cm}$ sub rebordul costal, splenomegalie gradul II, hemoroizi externi, sindrom meningean absent. Datele de laborator arată un sindrom inflamator (VSH $=120 \mathrm{~mm} / 1$ h, $140 \mathrm{~mm} / 2 \mathrm{~h}$ ), anemie hipocromă normocitară formă medie $(\mathrm{HGB}=8,2 \mathrm{mg} / \mathrm{dl}$, $\left.\mathrm{MCH}=27 \mathrm{pg}, \mathrm{MCV}=88 \mu \mathrm{m}^{3}\right), \mathrm{Ag}$ HBs absent, Atc VHC absenți, anticorpi IgG Toxoplasma gondii, citomegalovirus prezenți, test Elisa anticorpi anti-HIV1,2 pozitiv, Western Blot HIV pozitiv, încărcătură virală $\mathrm{HIV}=755.000$ copii $/ \mathrm{ml}, \mathrm{CD} 4=131$ celule $/ \mathrm{mm}^{3}$.

Radiografie pulmonară: nimic activ pleuro-pulmonar.

Ecografie abdominală: hepatomegalie importantă lob drept hepatic $=17,3 \mathrm{~cm}$; splenomegalie $=16,5$ $\mathrm{cm} / 8 \mathrm{~cm}$, splină neomogenă, cu multiple zone hipoecogene, difuz conturate, infracentimetrice; zone de fluid în cavitatea pleurală dreaptă și în pelvis.

Consult hematologic: sindrom limfoproliferativ (limfom în observație). Este recomandat consultul chirurgical în vederea biopsiei ganglionare cu examen histopatologic și efectuare examen computer-tomografic torace și abdomen.

Diagnostic de etapă: infecție cu HIV categoria C3 caz nou diagnosticat. Formațiune tumorală latero-cervical drept (adenită tuberculoasă? limfom?). Anemie hipocromă normocitară forma medie. Hemoroizi externi.

Evoluție și tratament: După biopsia ganglionară (efectuată la Clinica Chirurgie, Spitalul Clinic Județean de Urgență Craiova), pacienta revine la Compartimentul HIV/SIDA prezentând stare generală influențată, febră; cicatrice latero-cervicală dreaptă (postbiopsie ganglionară), $\mathrm{SaO}_{2}=99 \%$, alură ventriculară = 117 bătăi pe minut, tensiune arterială = 102/56 mmHg. Tabloul biologic arată leucocitoză cu neutrofilie, anemie hipocromă normocitară formă medie, sindrom inflamator $(\mathrm{VSH}=140 \mathrm{~mm} / 1 \mathrm{~h}, 160$ $\mathrm{mm} / 2 \mathrm{~h}$ ), Staphylococcus aureus prezent în hemocultură, sindrom de hepatocitoliză. 
La examenul computer tomografic torace cu substanță de contrast, se observă multiple adenopatii, unele cu necroze în interior (supraclavicular, prevascular, paratraheal superior şi inferior, subcarinar, hilar, axilar), lichid în cantitate moderată în pericard, lichid în cantitate mică pleural dreapta, lamă de lichid pleural stânga, fără imagini de procese înlocuitoare de spațiu la nivelul ariilor pulmonare.

Examenul computer tomografic abdomen $\mathrm{cu}$ substanță de contrast evidenţiază: splină 12,84/9,70 $\mathrm{cm}$, structură neomogenă prin prezența de multiple formațiuni spontan hipodense, neiodofile, cu diametrul cuprins între 9,2 $\mathrm{mm}$ și 17,3/19 mm, diseminate pe întreaga arie splenică, cu aspect de determinări
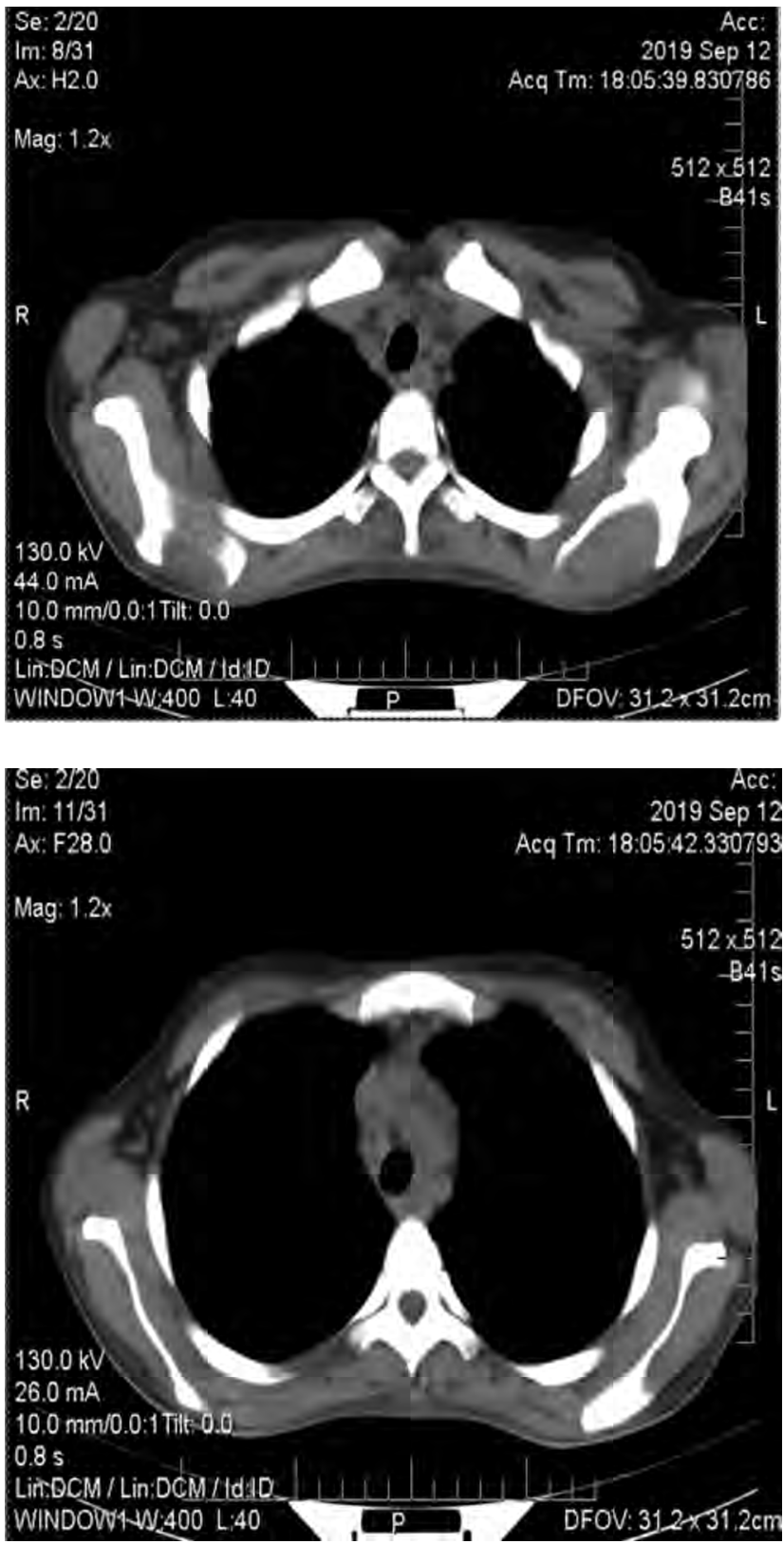

FIGURA 1A,B,C,D. CT torace granulomatoase. Nu se evidențiază adenopatii retroperitoneale și nici lichid în cavitatea peritoneală.

Deoarece starea pacientei se agravează progresiv, prezintă croșete febrile, se instituie tratament antibacilar cu Izoniazidă + Rifampicină + Etambutol + Ofloxacină, 7/7 până la primirea rezultatului histopatologic. După aproximativ 14 zile de la efectuarea biopsiei, se primește rezultatul examenului histopatologic ce evidențiază ganglion limfatic cu arhitectură distorsionată prin numeroase granuloame epitelioide, cu abundentă necroză și rare celule multinucleate de tip Langhans. Aspect de adenită cronică granulomatoasă, cel mai probabil de tip tuberculoză (TBC). Colorația Ziehl Nilson evidențiază pe frotiu Mycobacterium tuberculosis.
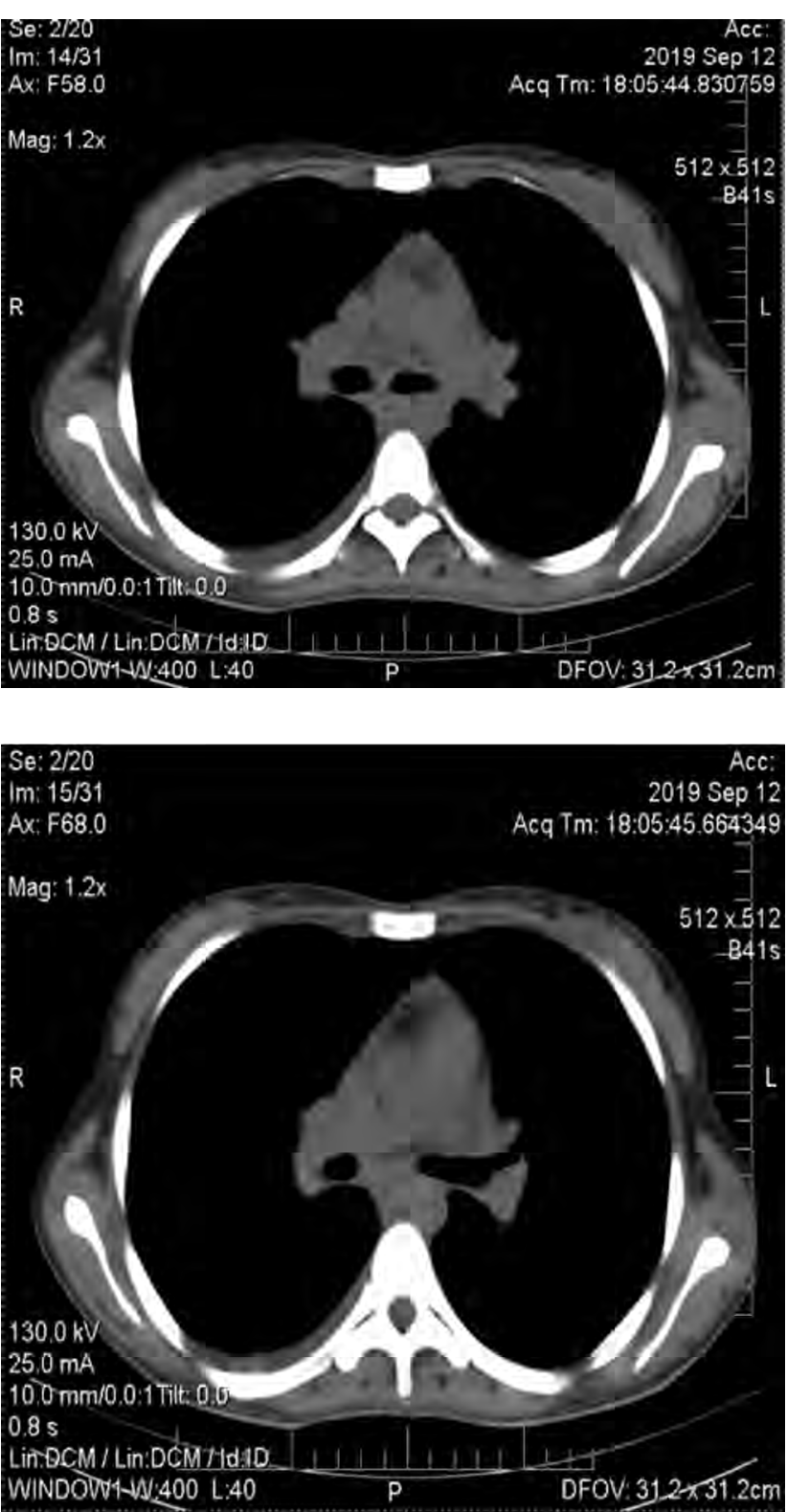


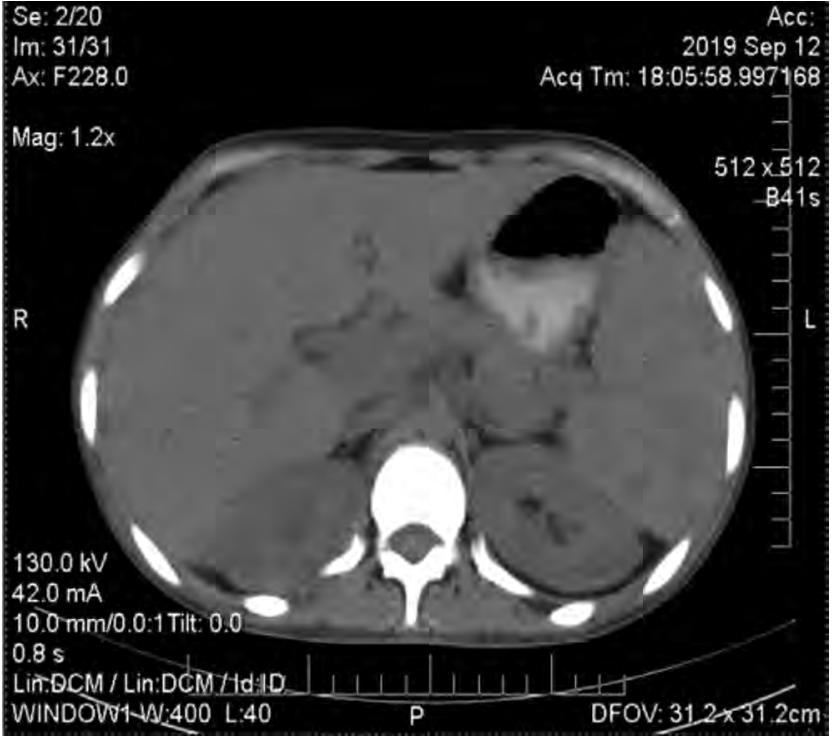

FIGURA 2A, B. CT abdomen

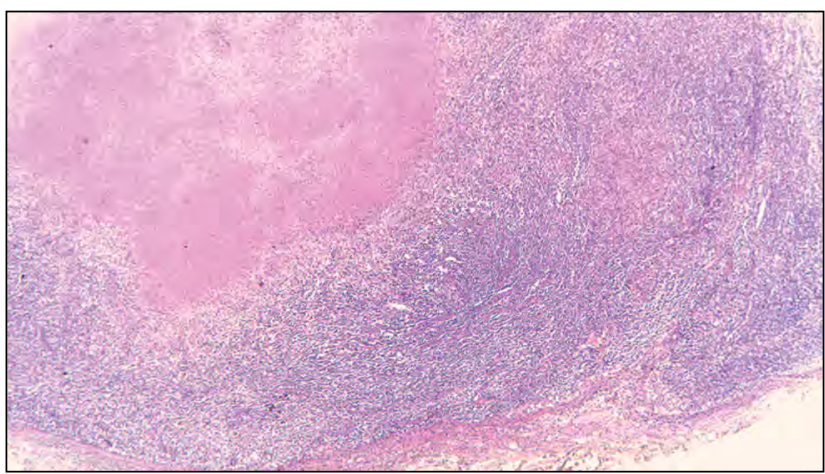

FIGURA 3A. Granuloame epitelioide și cazeoase confluente, col. HE, $x 40$

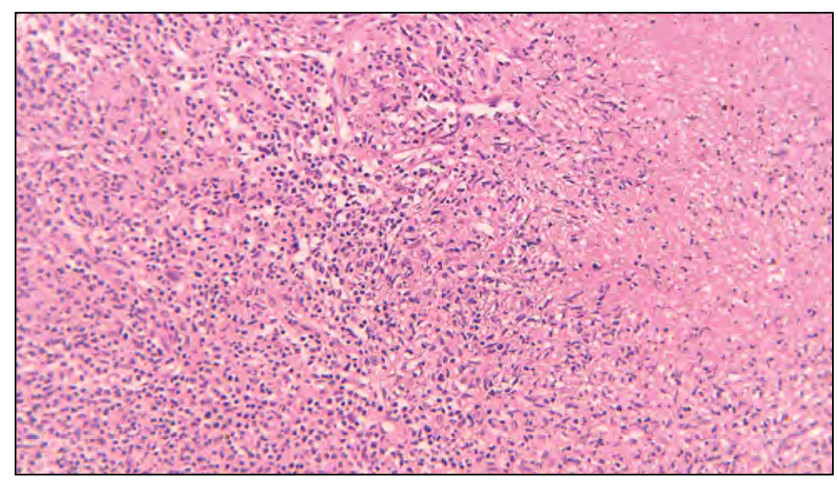

FIGURA 3C. Granuloame epitelioide și cazeoase confluente, col. HE, $x 100$, secţiune 2

Terapia antiretrovirală cu Tenofovir + Emtriva + Tivicay (TDF+FTC+DLG) este iniţiată după 10 zile de la iniţierea tratamentului antibacilar. Pe parcursul spitalizării, după circa 2 săptămâni de la iniţierea ART, pacienta acuză dureri lombare intense, cu iradiere la nivelul membrelor inferioare. Având în vedere simptomatologia pacientei și patologia asociată, se suspicionează IRIS, TBC cu determinare osoasă.

Valoarea limfocitelor CD4 $=331$ celule $/ \mathrm{mm}^{3}$.
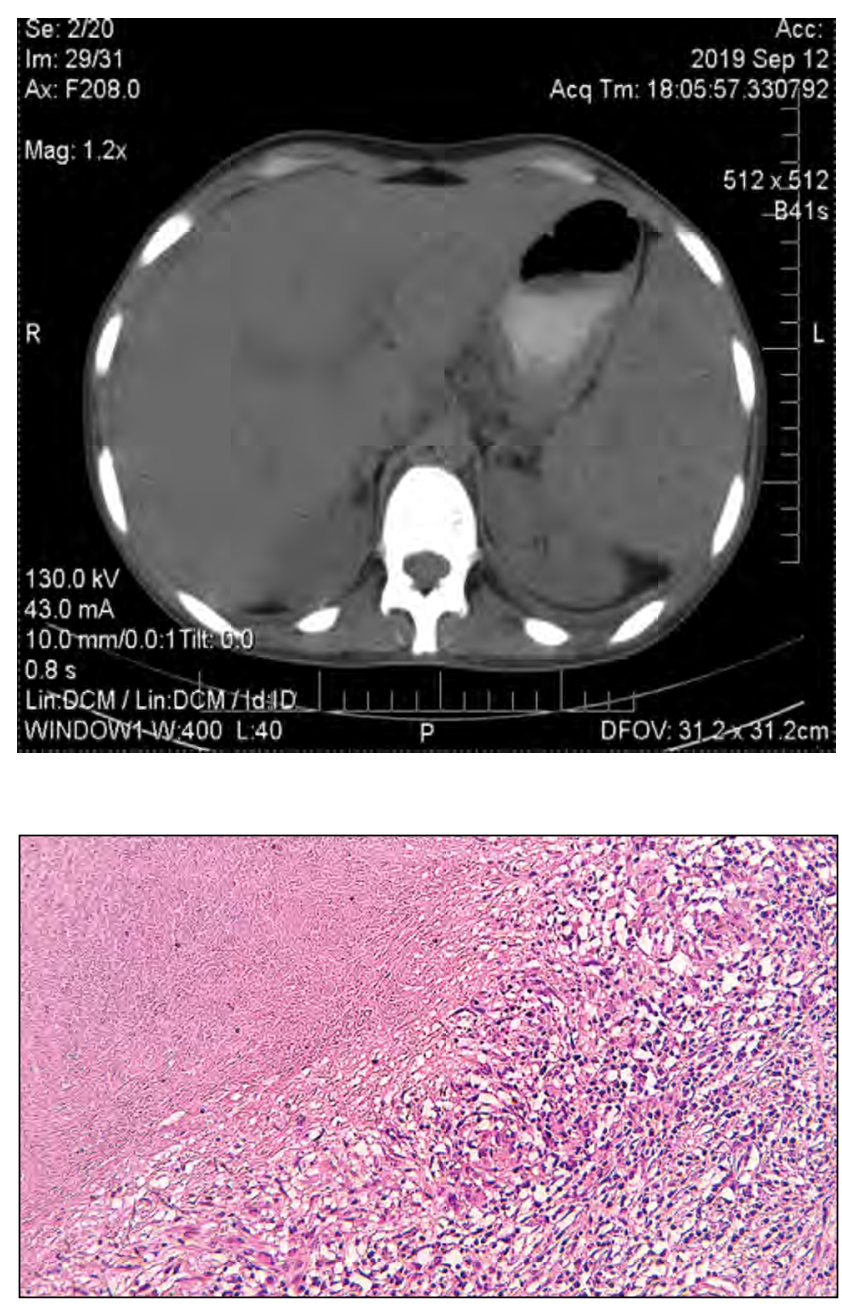

FIGURA 3B.Granuloame epitelioide și cazeoase confluente, col he, $x 100$, secţiune 1

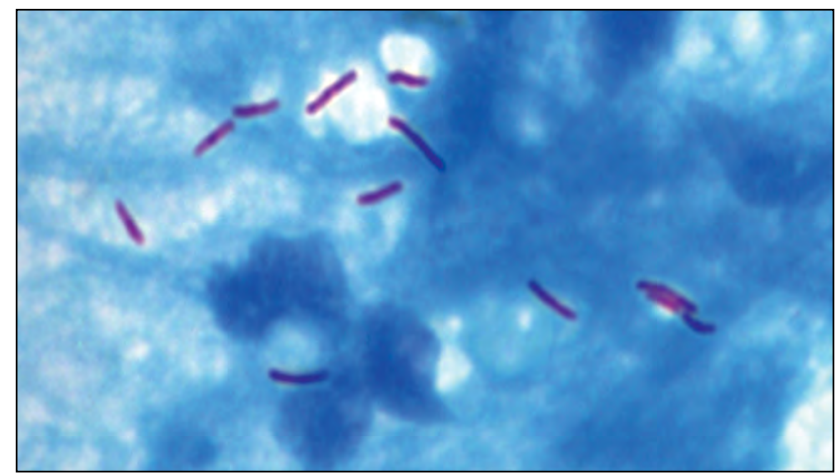

FIGURA 3D. Mycobacterium tuberculosis, col. Ziehl Nilson, $x 1000$

Pacienta a urmat tratament cu: antiretrovirale, antibacilare, corticoterapie (8 zile), antibioterapie (conform antibiogramei pentru Staphylococcus aureus), antialgice, protectoare gastrice și hepatoprotectoare.

Diagnosticul de tuberculoză osoasă este infirmat însă de examenul imagistic (IRM coloană lombară, octombrie 2019), ce evidenţiază hernie de disc lombosacrată L4-L5, L5-S1. 
Pacienta este externată după 6 săptămâni, cu stare generală ameliorată, afebrilă, echilibrată cardio-respirator, cu remisia parțială a simptomatologiei neurologice, cu recomandarea de a continua ART, tratamentul antibacilar şi de a urma program de kinetoterapie.

Diagnostice externare: infecție cu HIV categoria C3. Tuberculoză extrapulmonară cu determinări ganglionare și probabil splenice. Bacteriemie cu Staphylococcus aureus. Hernie de disc lombo-sacrată L4-L5, L5-S1. Anemie hipocromă normocitară formă medie. Candidoză orofaringiană. Seroreactiv Toxoplasma gondii $\mathrm{IgG}+$. Seroreactiv citomegalovirus $\operatorname{IgG}+$.

\section{DISCUȚII}

Majoritatea studiilor referitoare la IRIS efectuate până în prezent sunt retrospective şi au raportat că 17-32\% dintre pacienţii cărora li s-a iniţiat ART au dezvoltat IRIS, dar incidenţa globală a sindromului rămâne necunoscută. Un studiu prospectiv efectuat de către David M. Murdoch şi colab., în Africa de Sud, pe 423 pacienţi infectaţi HIV ART-naivi, a arătat că 44 pacienţi $(10,4 \%)$ au dezvoltat IRIS în primele 6 luni de terapie. Cele mai frecvente diagnostice au inclus tuberculoza (41\%), urmată de abcese şi foliculită $(18,2 \%)$, varicela zoster $(13,6 \%)$, herpes simplex (1\%), meningită criptococică $(6,8 \%)$, molluscum contagiosum (6,8\%) şi sarcom Kaposi (4,5\%) [5]. Cu toate acestea, întreruperea sau întârzierea ART de 2 până la 6 luni de la terapia TBC a fost asociată cu niveluri mari ale mortalităţii, făcând destul de dificilă decizia de a nu institui terapia asociată [6]. Într-un studiu retrospectiv (1 ianuarie 2013 - 31 decembrie 2017), efectuat la Centrul Regional de Monitorizare și Evaluare a Infecției HIV/SIDA Craiova, dintre 110 pacienți diagnosticaţi cu TBC, 5 cazuri au prezentat sindromul inflamator de reconstrucție imună asociată TBC după introducerea ART [7].

TBC poate apărea la orice număr de celule de limfocite T CD4, deși riscul crește odată cu imunodepresia progresivă. Apariția terapiei antiretrovirale a dus la o scădere a incidenței TBC în rândul persoanelor cu infecție HIV, dar, cu toate acestea, chiar și cu efectele benefice ale ART, riscul de TBC în rândul persoanelor cu infecție HIV rămâne mai mare decât cel al populației generale. Gestionarea optimă a tuberculo- zei legate de HIV necesită soluționarea ambelor infecții. Cotratamentul HIV și TBC este complex ca urmare a cerințelor de aderență a terapiei multidrog pentru două infecții, interacțiunilor medicamentoase, suprapunerii profilurilor cu efecte secundare ale medicamentelor anti-TBC și ARV și riscul IRIS. Tratamentul concomitent al HIV și TBC pentru pacienții coinfectați îmbunătățește supraviețuirea (în special pentru persoanele cu număr de CD4 $<50$ celule $/ \mathrm{mm}^{3}$ ) şi scade riscul de boli oportuniste suplimentare [8].

Persoanele infectate cu HIV au o densitate osoasă mai mică decât persoanele neinfectate [9]. Pierdere mai mare de densitate minerală osoasă (DMO) s-a observat la iniţierea anumitor ART, la regimuri care conțin TDF și unii inhibitori de protează (IP). Relevanța clinică legată de riscul de fracturi nu a fost determinată. Tenofovir alafenamida (TAF) a asociat mai puţine efecte adverse osoase determinate de administrarea de tenofovir, datorită unei expuneri sistemice mai mici la acest medicament [10]. Studiile de switch de la TDF la TAF sugerează o posibilă recurenţă a toxicităţii osoase. Cu toate acestea, experienţa pe termen lung cu TAF lipseşte. Factori clasici de risc pentru osteopenie: vârstă înaintată, sex feminin, hipogonadism, istoric familial de fractură de șold, BMI scăzut $\left(\leq 19 \mathrm{~kg} / \mathrm{m}^{2}\right)$, deficiență de vitamina $\mathrm{D}$, fumat, lipsă de activitate fizică, antecedente de fracturi la traumatisme minime, excesul de alcool $(<3$ unităţi/zi), expunere la steroizi (minimum $5 \mathrm{mg} /$ zi prednison sau echivalentul a $>3$ luni) [11].

În cazul pacientei noastre, am eliminat o reacție adversă la TDF cu ajutorul aspectului imagistic (IRMcoloană lombară), nefiind relevate modificări de tip osteopenie sau osteoliză. Deși IRIS putea să apară la această pacientă nou diagnosticată cu coinfecție HIV-TBC [12], a fost vorba de o suferinţă non-SIDA, hernie de disc lombo-sacrată.

\section{CONCLUZII}

IRIS trebuie avut în vedere la pacienții diagnosticați cu HIV în stadii tardive, la care introducerea ART poate fi urmată de agravarea sau apariția unei infecții oportuniste. Coinfecţia HIV-TB ridică probleme de tratament și diagnostic diferențial la pacienții nou diagnosticați cu imunodepresie severă. 


\section{BIBLIOGRAFIE}

1. Hoffmann, Rockstroh. Managing Side Effects. HIV Book 2016. www. hivbook.com.

2. Murdoch DM, Venter WD, Van Rie A, Feldman C. Immune reconstitution inflammatory syndrome (IRIS): review of common infectious manifestations and treatment options. AIDS Res Ther. 2007;4:9.

3. French MA, Lenzo N, John M, Mallal SA, McKinnon EJ, James IR, Price P, Flexman JP, Tay-Kearney ML. Immune restoration disease after the treatment of immunodeficient HIV-infected patients with highly active antiretroviral therapy. HIV Med. 2000;1(2):107-115.

4. Mitrea M, Bîrluţiu V, Deac M. Sindromul de reconstrucție inflamatorie imună (IRIS). Acta Medica Transilvanica 2010;2(1):100-102.

5. Murdoch DM, Venter WD, Feldman C, Van Rie A. Incidence and risk factors for the immune reconstitution inflammatory syndrome in HIV patients in South Africa: A prospective study. AIDS. 2008; 22(5):601-610.

6. Lawn SD, Bekker LG, Miller RF. Immune reconstitution disease associated with mycobacterial infections in HIV-infected individuals receiving antiretrovirals. Lancet Infect Dis. 2005;5(6):361-373.

7. Florentina Dumitrescu, Augustin Cupşa, Andreea Cristina Stoian, Lucian Giubelan, Livia Dragonu, Mariana Stănescu, Irina Niculescu, Stefanita Diaconeasa. Tuberculosis in people living with HIVIAIDS.
Zilele Matei Balș. 2018, a XIV-a ediție a Zilelor Științifice ale Institutului Național de Boli Infecțioase „Prof. Dr. Matei Balș“, 31 oct-2 noiembrie 2018, volum de rezumate.

8. Guidelines for the Prevention and Treatment of Opportunistic Infections in Adults and Adolescents with HIV. Mycobacterium tuberculosis Infection and Disease. September 27, 2019. Available at http://www. aidsinfo.nih.gov/guidelines/html/4/adult-and-adolescentoi-prevention-and-treatment-guidelines.

9. Loiseau-Peres S, Delaunay C, Poupon S et al. Osteopenia in patients infected by the HIV. A case control study. Joint Bone Spine 2002;69:482-5.

10. Bone damage: screening and diagnosis. Available at https://www. eacsociety.org/files/guidelines-8.1.

11. Chowta MN, Kamath, Ramapuram JT, Shenoy KA, Hadigal S. Evaluation of Adverse Drug Reaction Profile of Drugs Used as First-Line Antiretroviral Therapy. Interdisciplinary Perspectives on Infectious Diseases 2018;2018:8095609.

12. Price $P$, Mathiot $N$, Krueger $R$, Stone $S$, Keane NM, French MA. Immune dysfunction and immune restoration disease in HIV patients given highly active antiretroviral therapy. Journal of Clinical Virology 2001;22(3):279-287. 